\title{
LEGITIMASI ISLAM: SEBUAH PEMBACAAN TEORETIS TENTANG WAHYU ALQURAN
}

\author{
Munirul Ikhwan \\ Universitas Islam Negeri Sunan Kalijaga, Yogyakarta \\ munir.ikhwan.id@gmail.com
}

\begin{abstract}
In the studies of the Qur'an, there is no central concept as that of the Qur'anic revelation itself. The revelation becomes a symbol for God's unique communication to humans through human agency, called a prophet. Studies on the Qur'anic revelation by classical Muslim scholars have stressed much on its metaphysical aspects, while modern scholars like Toshiko Izutsu begin offering theoretical readings of the Qur'anic revelation as a linguistic concept, i.e., metaphysical communication expressed in a certain language system. By reviewing the existing studies, this article pays special attention to the sociological significance of the revelation. This study examines how revelation as an act of God arises in a setting of human history, and the extent to which it must correspond and dialogue with the values, institutions, and socio-cultural systems of its first audience. This study sees that the power of the Qur'anic revelation lies in its ability to build legitimacy and to integrate its first audience into a broader horizon that allowed them to participate in the contestation of religious discourse with older religious communities.
\end{abstract}

Keywords: Revelation, Unique Communication, First Audience, Legitimacy, Contestation of Religious Discourse

Abstrak: Dalam kajian-kajian Alquran, tidak ada konsep paling sentral kecuali konsep wahyu Alquran itu sendiri. Wahyu tersebut menjadi simbol bagi komunikasi unik dari Tuhan kepada manusia melalui agensi manusia, yang disebut nabi. Kajian-kajian tentang wahyu Alquran oleh sarjana Muslim klasik banyak menekankan pada aspek metafisiknya, sementara sarjana modern seperti Toshiko Izutsu mulai menawarkan pembacaan teoretis wahyu Alquran sebagai konsep linguistik, yaitu komunikasi metafisik yang terekspresikan dalam sistem bahasa tertentu. Dengan menelaah kembali kajian-kajian yang telah ada, artikel ini memberikan perhatian khusus pada signifikansi sosiologis wahyu. Studi ini mengkaji bagaimana mana wahyu sebagai tindakan Tuhan muncul dalam setting sejarah manusia, dan sejauh mana ia harus berkorespondensi dan berdialog dengan nilai, institusi, dan sistem sosial-kebudayaan audiens pertamanya. Studi ini melihat bahwa kekuatan wahyu Alquran terletak pada kemampuannya dalam membangun 
legitimasi dan mengintegrasikan audiens pertamanya dengan horizon yang lebih luas yang memungkinkan mereka ikut serta dalam kontestasi wacana keagamaan dengan komunitas agama yang lebih tua.

Kata Kunci: Wahyu, Komunikasi Unik, Audiens Pertama, Legitimasi, Kontestasi Wacana Keagamaan.

\section{Pendahuluan}

Tidak ada konsep paling sentral dalam kajian Alquran kecuali konsep wahyu Alquran itu sendiri. Wahyu dipandang tidak hanya sebagai asal mula (origin) Alquran, namun juga sebagai legitimasi risalah Islam. Di banyak literatur ilmu Alquran klasik seperti yang ditulis oleh Badr al-Dīn al-Zarkashī (m. 794/1392) maupun Jalāl alDīn al-Suyuṭi (m. 911/1505), pembahasan wahyu menitikberatkan pada ragam teori teologi metafisik tentang proses turunnya wahyu dari lauh mahfüz (buku catatan yang tersimpan) ke bayt al-iqzah (rumah keagungan) di langit dunia (al-samä' al-dunyà) dan kemudian turun ke bumi, dan juga teori tentang proses wahyu tersebut sampai kepada Nabi Muhammad. ${ }^{1}$ Sarjana Muslim modern seperti Mannā' al-Qațān dan Nūr al-Dīn 'Itr mulai menekankan konsep wahyu sebagai komunikasi rahasia dan cepat (al-iläm al-khafí al-sarı'; ilqàa' 'ilm fì ikhfä), namun belum mampu mengkonseptualisasikannya dalam tawaran teori yang jelas karena harus berhadapan dengan ragam interpretasi tentang kondisi-kondisi turunnya wahyu sebagaimana disebut di dalam redaksi Alquran dan hadis. ${ }^{2}$

Kajian teoretis dan non-teologis wahyu Alquran dilakukan oleh Toshihiko Izutsu yang memberi tekanan pada wahyu sebagai konsep linguistik. Artinya, wahyu Alquran merupakan komunikasi antara dua entitas dari level wujud yang berbeda di mana pihak pertama, yang berasal dari level wujud yang lebih tinggi (Tuhan), memilih menyesuaikan sistem bahasa yang dipakai dan dipahami oleh pihak kedua (Nabi Muhammad). Proses awal komunikasi ini bersifat rahasia karena hanya Tuhan dan Nabi yang terlibat. Namun, karena Nabi sebagai rasul mengemban misi untuk menyampaikan wahyu (balägh), maka wahyu tersebut beralih menjadi komunikasi publik. Izutsu

\footnotetext{
${ }^{1}$ Badr al-Dīn al-Zarkashī, Al-Burhān fì 'Ulüm al-Qur'ān, ed. Muhammad Abū al-Fạ̣l Ibrāhīm, vol. 1 (Kairo: Dār al-Turāth, 2000), 229-32; Jalāl al-Dīn al-Suyūṭi, Al-Itqān fì 'Ulüm al-Qur'ān, vol. 1 (Kairo: Dār al-Turāth, 1985).

2 Mannā' al-Qațāān, Mabāhith fì 'Ulüm al-Qur'ān (Kairo: Maktabat Wahbah, 2000), 26-34; Nūr al-Dīn 'Itr, 'Ulūm al-Qur'ān al-Karìm (Damaskus: Maṭba'at al-Ṣabāḥ, 1993), 14-26.
} 
menyorot fakta bahwa kepercayaan tentang model komunikasi antara dua pihak dari level wujud yang berbeda bukan merupakan hal baru di dalam konteks Arab abad ke-7 M. Audiens pertama Alquran telah mengakui kemungkinan model komunikasi ini dengan fenomena penyair (shä́rir) dan peramal (kähin) yang dipercaya mampu berkomunikasi dengan entitas supranatural, yang dipercaya sebagai jin. ${ }^{3}$ Teori Izutsu ini kemudian diadopsi oleh Naṣr Ḥāmid Abū Zayd dalam membaca ulang literatur ilmu Alquran Muslim klasik, terutama karya al-Zarkashī dan al-Suyūṭī. ${ }^{4}$

Bertolak dari kajian-kajian terdahulu, artikel ini mencoba mengulas kembali konsep dan teori wahyu Alquran dengan tidak hanya menempatkannya sebagai konsep linguistik, namun juga sebagai fenomena sosiologis. Konsep linguistik wahyu Alquran didasarkan pada fakta bahwa aspek linguistik menjadi identitas dasar Alquran dalam keterlibatannya dalam dinamika dan perdebatan dengan audiens pertamanya. Sementara itu, wahyu sebagai fenomena sosiologis menekankan pada aspek bahwa wahyu tersebut muncul sebagai fenomena sosial keagamaan dalam setting tertentu kesejarahan manusia. Ia berkorespondensi dan berdialektika dengan nilai, institusi, dan sistem sosial-kebudayaan audiens pertamanya, dan selanjutnya muncul sebagai "teks paradigmatik" Islam yang redaksi dan kontennya mengikat komitmen pengikutnya. ${ }^{5}$ Studi ini melihat bahwa kekuatan wahyu Alquran terletak pada kemampuannya dalam membangun legitimasi dan tradisi baru yang memfasilitasi audiens pertamanya untuk ikut serta dalam kontestasi wacana keagamaan dengan komunitas agama yang lebih tua. Sebagai langkah metodologis, artikel ini menelaah terma-terma sentral yang terkait dengan konsep wahyu dalam urutan krononologisnya, jika memungkinkan. Terma-terma tersebut dianalisis dalam konteks masing-masing sebelum ditarik dan dikaitkan dengan konteks wahyu Alquran secara umum.

\footnotetext{
3 Toshihiko Izutsu, "Revelation as a Linguistic Concept in Islam," dalam Studies in Medieval Thought 5 (1962): 122-67.

${ }^{4}$ Naṣr Hāmid Abū Zayd, Mafhūm al-Nașs: Dirāsat fì 'Ulūm al-Qư'ān (Kairo: AlHai'ah al-Mișrīyah al-'Āmmah li al-Kitāb, 1990).

${ }^{5}$ Brinkley Morris Messick, The Calligraphic State: Textual Domination and History in a Muslim Society (Berkeley, LA \& London: University of California Press, 1996), 16.
} 


\section{Konsep Wahyu Alquran}

Perlu kita tekankan sejak awal bahwa Alquran tidak sekedar menjadi kitab suci umat Islam, namun juga merupakan titik tolak sejarah Islam. Konseptualisasi Islam tentang wujud dimulai dengan titah Tuhan yang menghendaki terciptanya alam yang disimbolkan dengan kaläm (firman): "kun fa yakün" (jadilah, maka terjadilah). Wahyu di dalam Islam juga mengindikasikan awal sejarah Islam yang dimulai dengan kalam Tuhan. Ada beberapa konsep yang dipakai Alquran untuk menyebut proses komunikasi unik antara Tuhan dan Nabi Muhammad: wahyu, tanæill, dan kaläm Allah. Namun, sebutan "wahyu" menjadi konsep paling generik yang dipakai Alquran, dan juga merupakan konsep yang menghubungkan Alquran dengan horizon audiens pertamanya dan horizon tradisi keagamaan pra-Islam. Oleh karena itu, tradisi dan kultur Arab pra-Islam (jäbilìyah) tidak dapat dianggap sebagai sesuatu yang secara esensial terpisah dari Islam, namun sebagai ruang dialektika terbuka yang melibatkan beragam agensi kultural. ${ }^{7}$ Dengan kata lain, kultur dan tradisi Arab pra-Islam adalah titik tolak epistemologis bagi wahyu Alquran untuk muncul dalam kesejarahan manusia.

Perlu diingat bahwa kata waby bukanlah kosakata baru yang diperkenalkan oleh Alquran. Keberadaannya dapat dilacak di dalam bait syair "jāhilī” (pra-Islam). Penyair pra-Islam ternama, Alqamah alFahl (m. 20 SH/603), menyebut kata waby yang menunjukkan komunikasi khusus antara dua pihak yang tidak dapat dipahami oleh pihak ketiga di dalam salah satu bait syairnya. Bait tersebut berbunyi:

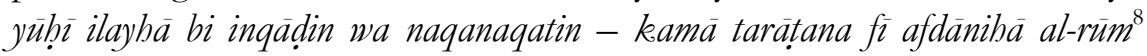
([burung unta jantan itu] berbicara kepadanya [burung unta betina] dengan suara melengking dan suara pejantan - sebagaimana orangorang Romawi berbicara [dalam bahasa yang tidak dipahami] di istana mereka). Dalam bait di atas, Alqamah menggunakan kata wahyu

6 Formula kun fa yakūn menekankan pada kuasa Tuhan sebagai Pencipta alam semesta. Formula ini tentu saja tidak harus dipahami sebagai kuasa penciptaan yang instan, sangat cepat, dan tanpa proses. Formula ini adalah simbol dari proses penciptaan Tuhan yang rumit sebagaimana al-Qur'an sendiri isyaratkan tentang penciptaan langit dan bumi (QS. 7:54) dan penciptaan embrio manusia (QS. 23:1214).

7 Angelika Neuwirth, Scripture, Poetry and the Making of a Community: Reading the Qur'an as a Literary Text (Oxford: Oxford University Press, 2014), xxi.

8 Aḥmad Muḥammad Shākir dan 'Abd al-Salām Muḥammad Hārūn (eds.), AlMufaddalìyàt (Kairo: Dār al-Ma‘ārif, 1942), 400. 
untuk mendeskripsikan komunikasi antara dua burung unta, dan komunikasi antar orang Romawi dalam bahasa mereka yang tidak dipahami oleh orang Arab. Di sini, wahyu dipakai untuk menunjukkan komunikasi lisan yang tidak dapat dipahami.

Di samping itu, kata wahy juga muncul di dalam bait syair praIslam yang menunjuk pada 'tulisan misterius' yang tidak dapat dipahami oleh orang Arab. 'Antarah b. Shadād (m. 15 SH/608), misalnya, menyebut dalam salah satu baitnya: ka waby sahä'if min 'ahd Kisrā - fa abdāhā li a jama timtimìy (seperti tulisan dalam lembaranlembaran dari masa Kisra - yang ia berikan kepada orang ajam yang tidak dipahami ucapannya). Contoh lain adalah bait dari Labīd b. Rabī'ah (m. 41/661): fa madäfi' al-rayyàn 'urriya rasmubā - khalqan kamā damina al-wubìy silamuba ${ }^{-10}$ (maka karena hembusan angin di gunung Rayyan itu tampaklah pahatannya - bak ciptaan sebagaimana batunya itu memuat tulisan-tulisan [wuhij]]). Dua bait di atas menunjukkan ekspresi kedua penyair yang merespons tulisan yang tidak mereka pahami. Bait dari syair Labīd, terutama, menunjukkan bahwa tulisan di atas batu di gunung Rayyan mengandung pesan, namun ia tidak paham apa makna pesan tulisan itu. ${ }^{11}$ Dengan demikian, wahyu dalam syair Arab pra-Islam secara etimologis menunjukkan makna komunikasi baik lisan maupun tulisan yang tidak dipahami oleh pihak ketiga sehingga menjadi misteri.

Senada dengan pola kultural di atas, wahyu di dalam Alquran juga dipakai sebagai "komunikasi misterius" antara dua pihak. Cerita tentang isyarat Nabi Zakariya kepada kaumnya untuk bertasbih di pagi dan sore hari, misalnya, menunjukkan makna ini. Fa kharaja 'alā qawmibì min al-miḅäb fa awhä ilaybim an sabbihüh bukratan wa 'ashìyan (Maka dia keluar dari mihrab menuju kaumnya, lalu dia memberi isyarat kepada mereka; bertasbihlah kamu pada waktu pagi dan sore hari; QS. 19:11). Isyarat Zakaria ini terkait dengan nazarnya untuk tidak berbicara jika Tuhan benar-benar menganugerahinya calon keturunan di kala ia dan istrinya telah memasuki usia senja. Dalam konteks ini, komunikasi misterius terjadi antara dua pihak dalam level wujud yang sama, yaitu antar manusia.

9 Abū 'Abd Allāh al-Qurțubī, Al-Jāmi' li Aḥkām al-Qur'àn, ed. 'Abd Allāh b. 'Abd alMuhsin al-Turkī, vol. 13 (Beirut: Mu'assasat al-Risālah, 2006), 422.

10 Abū 'Abd Allāh al-Husayn b. Aḥmad al-Zawzan̄i, Sharḥ al-Mu'allaqāt al-Sab' (Beirut: Lajnat al-Taḥīiq fī al-Dār al-'Ālamīyah, 1992), 89.

11 Abū Zayd, Mafhüm al-Nass, 62. 
Di ayat lainnya, Alquran memakai wahyu dalam konteks komunikasi misterius antara dua pihak dalam level wujud yang berbeda. Dalam QS. 28:7, misalnya, wahyu dipakai untuk menunjuk komunikasi antara Tuhan dan manusia: Wa awhaynà ilà umm mùsā an ardi îh (Dan Kami ilhamkan kepada ibu Musa, "Susuilah dia [Musa]!"). Di ayat lain, wahyu dipakai untuk mendeskripsikan komunikasi antara Tuhan dan hewan: $W$ a awḥa rabbuka ilā al-nabl an ittakbidbīh min al-jibäl buyūtan wa min al-shajar wa min mā yárishün (Dan Tuhanmu mengilhamkan kepada lebah, "Buatlah sarang di gunung-gunung, di pohon-pohon kayu, dan di tempat-tempat yang dibikin manusia). Tuhan dalam hal ini tentu saja berada dalam level wujud yang lebih tinggi karena Tuhan dalam konsepsi Alquran dan audiens pertamanya adalah Sang Pencipta atau asal dari wujud itu sendiri (QS. 96:1; 29:61; 31:25; 39:38; 43:9, 87, 39:62). Sementara itu, manusia dan hewan merupakan makhluk, entitas wujud yang lebih inferior dari Tuhan.

Senada dengan makna ini, Alquran juga menggunakan kata wahyu untuk menunjuk komunikasi Allah dengan Nabi Muhammad seperti QS. 4:163: innā awḥaynà ilayk kamā awhayna ilā nụ̣ wa al-nabiyyin min ba'dih (sesungguhnya kami wahyukan kepadamu sebagaimana kami telah wahyukan kepada Nuh dan nabi-nabi setelahnya). Namun, Alquran menggunakan kata tanzill atau in₹ăl (penurunan wahyu; QS. $3: 7 ; 12: 2 ; 32: 2 ; 36: 5 ; 39: 1 ; 40: 2 ; 41: 2,42 ; 44: 4 ; 56: 80 ; 69: 43 ; 97: 1)$ secara spesifik untuk menunjuk komunikasi antara Allah dan Nabi Muhammad. Berbeda dengan wahyu, baik tanzill maupun inz̧äl lebih menekankan pada model komunikasi vertikal. Argumen tentang komunikasi vertikal ini, sebagaimana Izutsu kemukakan, dapat dilihat dari cara Alquran yang tidak menggunakan tanø̨l sebagai penunjuk tindakan penuturan (speech-act) yang terjadi antara dua manusia. Kata tanæīl cenderung menunjukkan jenis komunikasi khusus yang supranatural. ${ }^{12}$ Dari sini dapat disimpulkan bahwa wahyu yang diklaim Nabi Muhammad bukanlah pola komunikasi biasa. Wahyu di dalam Islam menunjuk pada tindakan penuturan dari Tuhan, yang merepresentasikan alam metafisik yang lebih tinggi, kepada manusia, yang merepresentasikan alam fisik.

Sebagai bagian dari fenomena keagamaan Islam, konsep wahyu seperti di atas tentu saja sangat bernuansa teologis. Wahyu tidak dapat ditarik ke wilayah rasionalisme "objektif" karena ia tak dapat diamati secara pasti dengan indra manusia. Wahyu tidak sepenuhnya

12 Izutsu, "Revelation as a Linguistic Concept," 125. 
merupakan objek empirik yang dapat dianalisis sepenuhnya dengan nalar manusia. Untuk itu, kita perlu mendekati wahyu secara fenomenologis, yaitu melihat wahyu sebagai fenomena yang hidup apa adanya sebagaimana dialami oleh pelakunya, atau membacanya dari perspektif unik orang pertama. ${ }^{13}$

Konsep wahyu sebagai komunikasi dua alam menyisakan pertanyaan di kalangan sarjana Muslim klasik Alquran. Pertanyaan tersebut setidaknya dapat diformulasikan sebagaimana berikut: Bagaimana komunikasi antara dua pihak dari dua alam dan level wujud yang berbeda bisa terjadi? Apa landasan konseptual dan kultural bagi kemungkinan terjadinya komunikasi beda alam ini? Untuk menjawab pertanyaan tersebut, kita perlu menggarisbawahi bahwa wahyu Alquran muncul dalam kultur masyarakat yang mengimani kemungkinan komunikasi manusia dengan entitas metafisik. Oleh karena itu, pertanyaan di atas dapat dijelaskan dengan dua kemungkinan: pertama, manusia melepaskan sifat fisiknya dan berpindah sementara dari alam fisik ke alam metafisik, atau kedua, Tuhan mengutus utusan untuk masuk ke alam fisik (dunia) dan menyampaikan pesan-Nya kepada manusia. ${ }^{14}$ Dua kemungkinan jawaban tersebut didasari pada teori bahwa komunikasi antara kedua belah pihak hanya mungkin terjadi di dalam alam yang sama.

\section{Dua Fase Turunnya Wahyu Alquran}

Dalam hadis yang disandarkan kepada 'Ā'ishah b. Abū Bakr (m. 678/58), ${ }^{15}$ awal mula datangnya wahyu kepada Nabi adalah melalui mimpi (al-ru'yà al-șädiqab). Karena tidak mengerti makna mimpi tersebut, Nabi kemudian tergerak untuk menyendiri di gua Hira' selama beberapa waktu, berpisah dengan keluarganya, hingga pada suatu saat Jibril mendatanginya. Dalam riwayat ini, Jibril berbicara kepada Nabi, "Bacalah!". Nabi pun menjawab, "Aku tidak bisa membaca/apa yang harus aku baca ( $m \bar{a}$ anà bi qāri)?"16 Malaikat

13 Anna-Teresa Tymieniecka, "Introduction: Phenomenology as the Inspirational Force of Our Times," dalam Phenomenology World-Wide, ed. Anna-Teresa Tymieniecka (Dordrecht: Springer Science+Business Media, 2002), 1-8.

14 Abū Zayd, Mafbūm al-Nașs, 52.

15 Abū 'Abd Allāh Muhammad b. Ismā‘îl al-Bukhārī, Șaḥị al-Bukhārn̄ (Damaskus \& Beirut: Dār Ibn Kathīr, 2002), hadis no. 3.

${ }^{16}$ Karena tidak ada indikasi yang kuat dalam redaksi hadis di atas, " $m \bar{a}$ " dalam $m \bar{a}$ ana bi-qāri' mempunyai dua kemungkinan makna: pertanyaan (istifhām) dan penegasian (nafy). Kedua makna ini akan dielaborasi dalam diskusi di bawah. 
memegangi Nabi dengan memberi tekanan, kemudian melepaskannya kembali, dan mengulangi perintah yang sama "Bacalah!". Nabi pun memberi jawaban yang sama, "Aku tidak bisa membaca/apa yang harus aku baca?" Setelah terulang beberapa kali, Jibril pun membacakan QS. 96:1-5,

Bacalah dengan nama Tuhanmu yang mencipta

Menciptakan manusia dari segumpal darah

Bacalah dan Tuhanmu adalah yang Paling Mulia

Yang mengajarkan dengan pena

Mengajarkan manusia apa yang tidak diketahuinya

Menurut riwayat tersebut, pengalaman pertama Nabi bertemu malaikat membuatnya merasa takut dan tertekan, hingga sekembalinya ke rumah Nabi meminta istrinya, Khadijjah b. Khuwaylid (m. 619/3 $\mathrm{SH}$ ), untuk menyelimutinya. Ketakutan Nabi tampaknya berlangsung cukup lama hingga membuat Khadījah khawatir dengan kondisi suaminya tersebut. Khadijah yang cukup familiar dengan tradisi ahli kitab ${ }^{17}$ mencari jawaban dan terdorong untuk membawa Nabi kepada sepupunya, Waraqah b. Nawfal (m. 610/13 SH), yang dikenal banyak mempelajari dan mengikuti ajaran Kristen. Mendengar cerita Khadijjah tentang pengalaman suaminya tersebut, Waraqah menyimpulkan bahwa Muhammad akan menerima misi ketuhanan sebagaimana Musa dulu, dan karena misi tersebut ia akan mendapatkan penentangan hebat dari banyak orang.

17 Ibn Ishạa menyabutkan bahwa ketika Nabi pergi ke Syam bersama Maysarah membawa dagangan Khadījah b. Khuwaylid, sesampainya di Syam Nabi singgah di daerah dekat sebuah gereja. Ketika Nabi sedang duduk di bawah sebuah pohon, seorang pendeta mendatangi Maysarah menanyakan perihal pemuda yang duduk di bawah pohon tersebut. Menjawab bahwa pemuda itu dari Makkah, Maysarah penasaran mengapa pendeta tersebut menanyakan hal itu. Sang Pendeta menjawab bahwa pemuda yang duduk di bawah pohon itu suatu saat akan menjadi nabi. Pendeta itu lantas meminta Maysarah memperhatikan tanda-tanda yang tidak biasa selama perjalanan kembali ke Makkah nanti. Sesampainya di Makkah, Maysarah menceritakan penilaian pendeta di Syam itu tentang Nabi. Mendengar cerita tersebut, lantas Khadijah membulatkan tekad untuk melamar Nabi. Cerita ini tentu saja dapat diperdebatkan kebenarannya. Namun, ini adalah cerita yang merefleksikan narasi populer Muslim tentang adanya tanda-tanda luar biasa sebelum kenabian Muhammad. Terlepas dari pertanyaan seputar kebenarannya, cerita ini mengilustrasikan bahwa Khadijah telah mengenal tradisi Ahli Kitab, dan mempunyai kecenderungan ke tradisi keagamaan Ahli Kitab. Ramalan pendeta tentang kenabian Muhammad mendorong Khadijah untuk melangkah mantap menikah dengan Nabi. Muḥammad b. Isḥāq, Al-Sìrah al-Nabawìyah, ed. Aḥmad Farīd al-Mazīdī (Beirut: Dār al-Kutub al-'Ilmīyah, 2004), 128-29. 
Berdasarkan riwayat di atas, kita dapat membuat analisis bahwa wahyu Alquran turun dalam dua fase. Fase pertama adalah turunnya wahyu yang terjadi di alam metafisik (melalui mimpi), dan fase kedua terjadi di alam fisik (gua Hira'). Dalam hal ini, QS. 96:1-5 adalah isi dari pesan metafisik yang belum tertangkap oleh Nabi atau manifestasi pesan dalam mimpi Nabi ke dalam pesan fisik. Pada fase metafisik, wahyu tidak mungkin dalam bentuk verbal karena komunikasi dalam bahasa Arab hanya bisa dipahami jika terjadi di alam fisik. Karena menerima wahyu melalui mimpi merupakan pengalaman pertama Nabi, maka dapat dipahami jika Nabi masih sulit mencerna maksud dari wahyu tersebut. Ini kemudian mendorongnya untuk menyendiri mencari jawaban dari "pesan misterius" tersebut, namun jawaban itu tak kunjung didapat hingga Jibril muncul. Permintaan Jibril agar Nabi membaca (iqra) sangat terkait dengan pesan metafisik yang diterima Nabi lewat mimpi tersebut. Jika " $m \vec{a}$ " dalam mà ana bi qäri' berarti pertanyaan, maka Nabi menanyakan kepada Jibril apa yang harus dibaca, mengingat Jibril datang tidak membawa material apapun untuk dibaca namun meminta Nabi untuk membaca. Namun, jika ' $m \vec{a}$ ” dalam mà ana bi qāri' berarti negasi, maka Nabi merespons Jibril bahwa ia tidak dapat membaca pesan yang diterimanya dalam mimpi. Mendengar respons Nabi ini, lantas Jibril membantu Nabi membacakan isi wahyu tersebut dalam bahasa Arab. Pembacaan wahyu oleh Jibril inilah fase kedua wahyu, yaitu komunikasi dalam sistem bahasa manusia.

Seiring dengan berjalannya waktu, tampaknya Nabi mulai terbiasa dengan pola turunnya wahyu. Nabi mulai memahami maksud wahyu dalam komunikasi metafisik dan berusaha melafalkannya ke dalam bahasa Arab. Namun, Nabi tampaknya masih dianggap belum sepenuhnya mampu mentransfer maksud komunikasi metafisik yang non-verbal itu ke dalam bahasa fisik yang verbal. Hal ini diilustrasikan di dalam QS. 75:16-19.

Jangan engkau gerakkan lidahmu karena hendak cepat-cepat dengannnya.

Sesungguhnya Kami yang akan mengumpulkannya (di dadamu) dan membacakannya.

Maka apabila Kami telah selesai membacakannya maka ikutilah bacaannya itu.

Kemudian sesungguhnya Kami yang akan menjelaskannya.

Turunnya wahyu Alquran dalam dua fase (metafisik dan fisik) ini juga diilustrasikan dalam riwayat lain yang disandarkan kepada 
'A' 'ishah. ${ }^{18}$ Dalam riwayat tersebut, Nabi ditanya tentang proses wahyu turun kepadanya. Nabi menjawab bahwa kadang-kadang wahyu turun seperti dering bel (salsalat al-jaras). Menurut Nabi, metode pewahyuan ini adalah yang paling sulit dari proses-proses lainnya; proses pewahyuan itu berlangsung begitu saja hingga Nabi memahami apa yang diwahyukan. Terkait proses ini, Aisyah menceritakan bahwa Nabi tampak berkeringat pada suatu hari yang sangat dingin ketika wahyu itu turun. Cara lainnya adalah Jibril datang dalam bentuk seorang pria dan berbicara kepada Nabi hingga Nabi paham maksud dari wahyu tersebut.

Abū Zayd termasuk sarjana Muslim yang memegang teori turunnya wahyu dalam dua fase (marb̧alatayn), bukan dua cara (hälatayn). ${ }^{19}$ Turunnya wahyu melalui mimpi, dering bel ataupun komunikasi metafisik lainnya adalah fase pertama, yaitu komunikasi non-verbal. Dan wajar jika Nabi sebagai manusia yang hidup dalam alam fisik merasa lebih sulit mencerna komunikasi pada level ini karena Nabi harus susah payah masuk ke dalam level alam yang lebih tinggi. ${ }^{20}$ Sementara itu, turunnya Jibril dalam bentuk manusia yang membacakan wahyu kepada Nabi adalah fase kedua, yaitu fase komunikasi verbal. Jibril dalam fase ini membantu mentransfer wahyu non-verbal yang turun dalam alam metafisik ke dalam bentuk verbal. Teori ini cukup masuk akal karena jika wahyu Alquran turun dalam dua cara (atau lebih), maka akan terjadi dikotomi antar bagian-bagian Alquran; sebagian wahyu diterima Nabi melalui komunikasi nonverbal, dan sebagian lainnya melalui komunikasi verbal. Implikasinya adalah munculnya kemungkinan pemahaman bahwa sebagian Alquran adalah hasil redaksi Nabi dari apa yang ia pahami dari komunikasi non-verbal, dan sebagian lainnya dibacakan oleh Jibril melalui komunikasi verbal. Sementara teori dua fase tanzīl menegaskan bahwa

\footnotetext{
18 Al-Bukhārī, Șahīh Al-Bukhārì, hadis no. 2.

19 Abū Zayd, Mafhüm al-Nașs, 59.

20 Mengamati fenomena sosiologis kenabian, Ibn Khaldūn menyebut bahwa alam manusia berada di bawah alam ruh yang merupakan alam pengetahuan dan penalaran murni. Inilah alam malaikat. Untuk mendapatkan pengetahuan dari alam malaikat, jiwa manusia harus mampu melakukan melapaskan diri dari alam manusia dan masuk ke alam malaikat. Setelah beberapa saat, jiwa manusia kembali ke alam fisik dengan membawa pengetahuan yang akan disampaikan kepada orang lain. 'Abd al-Raḥmān b. Khaldūn, Al-Muqaddimah, ed. 'Abd al-Salām al-Shadādī, vol. 2 (Casablanca: Bayt al-Funūn wa al-'Ulūm wa al-Ādāb, 2005), 346.
} 
semua bagian Alquran turun melalui dua fase: metafisik dan fisik, non-verbal dan verbal, tanpa terkecuali.

\section{Tekstualitas Wahyu dan Sistem Sosiolinguistiknya}

Alquran disebut sebagai kalam Allah dalam definisi teologis Islam. Definisi ini mempunyai implikasi bahwa Nabi Muhammad tidak mempunyai peran apapun terkait 'produksi' Alquran. Namun, penyebutan Alquran terhadap dirinya sebagai kalām Allah tidak sebanyak penyebutannya sebagai wahyu, kitab, atau tanžll. Di dalam QS. 48:15, "kalàm Allah" dipakai dalam konteks keinginan masyarakat Badui Arab yang selalu enggan berperang, namun tiba-tiba ingin dilibatkan ketika Nabi dan pengikutnya hendak mengambil harta rampasan. Keinginan mereka yang demikian ini disebut ingin mengubah "kalàm Allah" yang telah menegaskan karakter dasar mereka, yaitu keengganan berperang bersama Nabi. ${ }^{21}$ Sementara itu, di saat relasi Madinah dan Makkah memanas, QS. 9:6 mengizinkan Nabi memberikan proteksi kepada orang (musyrik) Makkah yang meminta perlindungan sehingga memungkinkannya untuk mendengar kalām Allah. ${ }^{22}$ Asosiasi Alquran sebagai kalām Allah sebenarnya lebih banyak diperbincangkan di luar teks Alquran sebagai implikasi dari konsep wahyu Alquran itu sendiri, sebagai firman Tuhan.

Alquran dalam definisi Islam adalah firman Tuhan yang tertulis. Alquran muncul sebagai fenomena 'unik' dalam konteks sosio-kultural Arab pra-Islam, terutama jika kita melihat bagaimana audiens pertama mengidentifikasi Alquran dengan identifikasi yang berbeda-beda, dan bagaimana respons Alquran terhadap identifikasi tersebut. Audiens pertama Alquran tentu saja tidak melakukan identifikasi di luar horizon mereka, yaitu konteks kebudayaan Arab pra-Islam. Mereka mengidentifikasi Alquran berdasarkan worldview dan nalar kebudayaan mereka, yang mengaitkan fenomena munculnya belle-lettres dengan relasi unik antara manusia dan entitas metafisik yang dipercaya sebagai jin. Audiens pertama, misalnya, mencoba mengidentifikasi Alquran sebagai penuturan manusia yang dirasuki jin (majnū; QS. 44:14; 52:29; 81:22), atau penuturan yang bersumber dari setan (qawl shaytän; QS. 81:25); dan keduanya disangkal oleh Alquran. Di ayat yang lain,

21 QS. 48:15 sayaqūl al-mukhallafün idhà intalaqtum ilā maghānim li-ta'khudhūhà dharūnà nattabi'kum yuridūn an yubaddilü kaläm Alläh, qul lan tattabi'ūnā.

${ }^{22}$ QS. 9:6, wa in ahad min al-mushrikin istajārak fa ajirh ḥattā yasma' kalām Allāh thumm ablighh ma'manah, dhälike bi annahum qawm là ya lamūn. 
Alquran juga menyangkal pendapat mereka bahwa apa yang disampaikan Nabi adalah penuturan (qaw) penyair (QS. 37:36; 69:41) atau penuturan peramal (kähin; QS. 52:29; 69:42). Penyair dan peramal dalam kultur Arab pra-Islam dipercaya mampu memproduksi ayatayat bersajak yang indah yang diapresiasi oleh masyarakat Arab praIslam sebagai sesuatu yang di luar kapasitas manusia. Fakta bahwa penuturan itu muncul dari manusia diterjemahkan oleh kultur Arab sebagai produk komunikasi dengan entitas metafisik atau inspirasi dari jin. ${ }^{23}$

Perbedaan identifikasi Alquran dengan berbagai sebutan (penuturan setan/jin, penyair dan peramal) menunjukkan bahwa Alquran sebagai tindakan penuturan tidak sepenuhnya dapat diidentifikasi dengan model-model penuturan yang telah dikenal oleh audiens pertamanya. Kita tidak memungkiri bahwa bagian-bagian tertentu dari Alquran mempunyai kemiripan dengan gaya penuturan sajak penyair atau peramal; namun, Alquran menolak identifikasiidentifikasi audiens pertamanya. Bagian pertama surah al-Ṭāriq [86], misalnya, memiliki kemiripan sajak dengan sajak ramalan, Zabra', seorang peramal perempuan dari Banī Ri'am dari kabilah Qudha'ah.

QS. 86:1-7

Wa al-samä' wa al-täriq

Wa mà adräk mà al-täriq

Al-najm al-thäqib

In kull nafs lammā 'alaybā a

băäiz

Falyanz̧ur al-insān min mā khuliq

Khuliqa min mä’ däfiq

Yakbruj min bayn al-sulb wa a

a

a

a a Maka hendaknya manusia

Demi langit dan yang datang di malam hari

Dan tahukah kamu apa yang datang di malam hari itu?

(Ia adalah) bintang yang bersinar tajam

Sungguh setiap jiwa itu pasti ada penjaganya atas dirinya itu melihat dari apa ia tercipta

a Ia tercipta dari air yang terpancar

Yang keluar dari antara

23 Izutsu menjelaskan bahwa jin dalam nalar Arab pra-Islam tidak berkomunikasi dengan setiap orang. Ia memilih orang-orang tertentu sebagai juru bicara di dunia; relasinya dengan manusia yang dipilih tersebut sangat personal. Toshihiko Izutsu, God and Man in the Qur'an: Semantics of the Qur'anic Weltanschaunng, ed. ke-2 (Petaling Jaya: Islamic Book Trust, 2008), 182-83. 
al-taräib

Innahū 'alà raj'ỉì laqādir

Yawm tublā al-saràir

Fa mà labū min quwwat wa là nāsir

Penuturan bersajak Zabra'

Wa al-lawḥ al-khäfiq

Wa al-layl al-ghāsiq

Wa al-sabāḥ al-shāriq

$W$ a al-najm al-täriq

Wa al-muzn al-wādiq

Inna shajara al-wādì laya'dū k.hatlā

Wa yạ̣ruq anyāban 'usla

Wa inna sakbra al-tawd layundbir thukla

Là tajid 'anh ma'la' tulang punggung dan tulang iga

b Sungguh Dia mempu untuk mengembalikannya (dari kematian)

b Pada hari ditampakkan semua rahasia

b Maka ia (manusia) tidak lagi mempunyai kekuatan dan tidak juga penolong

a Demi angin yang bertiup

a Demi malam yang gelap

a Demi pagi yang terang

a Demi bintang yang melintas

a Demi awan yang mendung

b Sesungguhnya pohon lembah itu mengentalkan persembunyiannya

b Dan membakar amarah yang mengerikan

b Dan sesungguhnya batu gunung itu mengingatkan pada kehancuran

b Kalian tidak temukan darinya tempat berlindung

Dapat dipahami jika memang Alquran harus berkorespondensi dengan gaya penuturan tertentu Arab pra-Islam, namun ia secara menyeluruh tidak mutlak mengikuti pola syair maupun penuturan bersajak peramal secara ketat. Alquran mengembangkan gaya penuturannya sendiri dan tentu saja pesan keagamaan menjadi distingsi yang omnipresent di dalam setiap penuturan Alquran. Muatan seperti ini yang membedakan Alquran dengan penuturan syair maupun ramalan Arab pra-Islam. Atas dasar inilah sarjana Alquran

24 Abū 'Alī Ismā'îl b. al-Qāsim al-Qāî̀, Kitāb al-Amātì wa al-Zayl wa al-Tanbīh, vol. 1 (Kairo: Al-Hai’ah al-Mișrīyah al-‘Āmmah li al-Kutub, 1975), 161. 
baik Muslim klasik (seperti Abū Bakr al-Bāqillānī, m. 403/1013), Muslim modern (seperti Ṭahā Husayn, m. 1973), maupun sarjana Alquran non-Muslim (seperti Theodor Nöldeke, m. 1930) mengkategorikan Alquran sebagai genre literatur tersendiri yang independen dari kategori-kategori penuturan Arab sebelumnya maupun sesudahnya. ${ }^{25}$

Perlu diperhatikan bahwa penuturan penyair, peramal, maupun Alquran semuanya bekerja dalam ruang dan prinsip penuturan yang sama yaitu, bahasa (lisān) Arab. Izutsu menawarkan analisis menarik ketika mengaitkan relasi antara Alquran sebagai tindakan penuturan (speech-act) dan bahasa yang menaunginya. Meminjam teori linguistik modern Ferdinand de Saussure, ia menyebut bahwa Alquran sebagai kalam adalah parole, sementara bahasa Arab yang 'dipilih Tuhan' sebagai media komunikasi dengan manusia adalah langue. ${ }^{26}$ Parole bersifat individual dan merefleksikan keunikan karakter, situasi intelektual, dan kondisi psikologis penuturnya. Namun demikian, parole tetap bekerja menurut kode dan struktur yang dimungkinkan oleh langue, yang merupakan payung bagi ragam penuturan dan konsensus sosial antar anggota masyarakat pemakainya. Dengan demikian, langue menjadi wilayah bersama bagi heterogenitas parole. ${ }^{27}$ Dalam konteks pembahasan wahyu Alquran, bahasa Arab menjadi wadah bagi penuturan yang heterogen, baik itu syair, sajak peramal, maupun Alquran.

Jika bahasa Arab adalah produk budaya yang hidup dalam masyarakat dan Alquran adalah parole yang bersifat individual dan bekerja dalam wilayah kode bahasa Arab, lantas apakah Alquran sebenarnya merefleksikan karakter dan psikologi Tuhan, atau justru sebaliknya Alquran lebih banyak merefleksikan karakter kemanusiaan? Pertanyaan kritis ini tidak hanya menyentuh wilayah teologis, namun

\footnotetext{
25 Abū Bakr Muḥammad b. al-Ṭayb al-Bāqillānī, I'jāza al-Qur'ān, ed. Aḥmad Ṣaqar, t.t, 51-70; Ṭāhā Husayn, Fī al-Shír al-Jāhilì (Kairo: Dār al-Kutub al-Mișrīyah, 1926), 17; Theodor Nöldeke, Neue Beiträge zur Semitischen Sprachwissenschaft (Straßburg: Verlag von Karl J. Trübner, 1910), 22; Nasr Hamid Abu Zayd, "The Dilemma of the Literary Approach to the Qur'an," dalam Alif: Journal of Comparative Poetics 23 (2003): $8-47$.

${ }^{26}$ Izutsu, "Revelation as a Linguistic Concept," 123-24.

${ }^{27}$ Ferdinand de Saussure, Course in General Linguistics, terj. Wade Baskin (New York: The Philosophical Library, 1959), 14.
} 
juga sering dianggap memunculkan spekulasi-spekulasi yang dapat meruntuhkan bangunan teologi Islam (Alquran sebagai kalam Allah). ${ }^{28}$

Terkait isu di atas, kita tidak bisa menolak fakta keimanan Muslim terhadap Alquran sebagai kalam Allah, namun kita juga perlu membaca fenomena ini tanpa harus melakukan spekulasi untuk menganalisis hal-hal di luar fakta empirik teks Alquran. Teks Alquran adalah objek yang bisa diobservasi bersama, dan ini menjadi titik tolak penting dalam mengkaji fenomena wahyu Alquran. Terkait pertanyaan mengapa Alquran turun dalam bahasa Arab, kita dapat mengadopsi perspektif teologis bahwa Tuhan memang menghendaki Alquran berbahasa Arab, karena tujuan utama dari wahyu tersebut adalah manusia. Ini sebenarnya hal yang wajar karena 'pembawa risalah' berbangsa Arab, demikian juga audiens pertamanya adalah masyarakat Arab abad ke-7 M. Alquran sendiri telah menegaskan bahwa para rasul diutus dengan menyesuaikan bahasa kaum mereka (Q.14:4).

Fakta di atas mempunyai konsekuensi hermeneutis bahwa untuk memahami wahyu Alquran, kita perlu menimbang aspek parole dari Alquran dan langue sebagai sistem sosio-linguistiknya, juga konteks yang melatari parole dan langue tersebut. Di kalangan sarjana Muslim, arah pembacaan ini ditegaskan oleh Amīn al-Khūlī (m. 1966) dalam proyek intelektualnya tentang reformasi tafsir Alquran. Menurut alKhūili, pembacaan Alquran harus dilakukan dengan melalui 2 proses analisis: teks dan konteks. Analisis teks (diräsah fì al-Qur'än) meliputi analisis penggunaan dan pilihan kosakata Alquran, dan analisis konstruk kalimat yang dipakai Alquran untuk mengekspresikan makna tertentu. Sementara itu, analisis konteks (diräsah mä hạwl al-Qur'än) adalah analisis konteks meterial dan immaterial yang melatari munculnya Alquran, sebagai "Kitab Berbahasa Arab Terbesar" (Kitāb

\footnotetext{
28 Muḥammad Aḥmad Khalāfallāh dan Naṣr Ḥāmid Abū Zayd adalah di antara pengusung pembacaan humanistik Alquran, yaitu pembacaan Alquran dalam horizon kemanusiaan. Pembacaan mereka terhadap Alquran oleh kelompok agamawan Mesir dianggap merendahkan Alquran sebagai firman Tuhan yang transendental. Karena tekanan-tekanan kelompok agamawan, Khalāfallāh harus menerima konsekuensi menulis ulang disertasinya, sedangkan Naṣr Hāmid Abū Zayd harus menghadapi tuduhan apostasi, dan oleh karenanya status pernikahannya dengan seorang Muslimah harus dibatalkan. Lihat, Abu Zayd, "The Dilemma of the Literary Approach," 8-47; Naṣr Hāmid Abū Zayd, Al-Tafkìr fì Zaman al-Takefir (Kairo: Sīnā li al-Nashr, 1995).
} 
al-'Arabiyah al-Akbar). ${ }^{29}$ Bagi kelompok Muslim progresif, analisis terhadap kedua aspek tersebut menjadi pijakan penting dalam membangun "keseimbangan hermeneutik" 30 dengan signifikansi pesan wahyu dalam konteks historis dan sosial yang berbeda.

\section{Antara Kenabian dan Kerasulan}

Klaim wahyu Alquran oleh Nabi Muhammad berimplikasi pada melekatnya konsep kenabian (nubuwwah) dan kerasulan (risälab) pada diri Nabi. Dengan kata lain, wahyu Alquran menjadikan figur Muhammad sebagai nabi dan juga rasul. Lantas apa perbedaan nabi dan rasul, dan apa landasan konseptual bagi pembedaan ini? Banyak pandangan disampaikan oleh teolog Muslim terkait definisi nabi dan rasul, namun pandangan umum bermuara pada definisi yang menempatkan konsep nabi lebih umum daripada rasul. Rasul adalah manusia yang mengklaim mendapatkan wahyu dan mempunyai misi untuk menyampaikan wahyu tersebut kepada orang banyak. Sementara itu, nabi adalah manusia yang mengklaim mendapatkan wahyu, namun ia tidak mendapat mandat untuk menyampaikannya. Dengan demikian, setiap rasul adalah nabi, namun tidak setiap nabi adalah rasul. ${ }^{31}$ Nabi tidak mempunyai misi publik sebagaimana rasul.

Konsep nubuwwah dan risälah dalam Islam dapat dipahami dari fenomena wahyu dan konsekuensi-konsekuensinya. Nubuwwah adalah konsep yang terkait erat dengan proses komunikasi vertikal yang menempatkan Nabi Muhammad sebagai audiens pertama dan audiens satu-satunya. Dengan demikian, nubumwah lebih bersifat personal. Sementara itu, risälah mempunyai konsekuensi kewajiban menyampaikan misi kepada khalayak ramai (tabligh, balagh). Dengan kata lain, risälah lebih menyentuh tugas publik. Fenomena nubuwwah dan risälab pada diri Nabi Muhammad menunjukkan bahwa pengetahuan tentang nubuwwah tidak boleh berhenti pada pribadi Nabi saja sebagai audiens pertama wahyu. Nubuwwah Nabi harus menjadi risälah atau misi umum yang diketahui dan disampaikan kepada publik. Sebatas "pengetahuan" tentang risälah tidak serta-merta menjadikan seseorang menjadi rasul karena hanya aktivitas tabligh-lah yang

29 Amīn al-Khūī̄, Manāhij al-Tajdìd fi al-Naḥw wa al-Baläghah wa al-Tafsìr wa al-Ādäb (Kairo: Maktabat al-Usrah, 2003), 233-39.

30 Sahiron Syamsuddin, Hermeneutika dan Pengembangan Ulumul Qur'an, Edisi Revisi dan Perluasan (Yogyakarta: Nawesea Press, 2017), 140.

31 Ṣa'd al-Dīn 'Alī b. Abī al-'Tzz al-Hanafī, Sharḥ al-Ṭahāwiyah (Riyad: Wizārat alShu'ūn al-Islāmīyah wa al-Awqāf wa al-Da'wah wa al-Irshād, 1997), 117. 
menambahkan nilai lebih seorang nabi menjadi rasul. ${ }^{32}$ Dengan demikian, wahyu Alquran mempunyai dua target: target nubuwwah yaitu Nabi Muhammad, dan tujuan risälah, yaitu manusia.

Karena wahyu mempunyai implikasi risälah, maka wahyu harus dapat dipahami oleh audiens risälah. Agar dipahami audiensnya, wahyu harus beradaptasi dengan horizon, tradisi, dan sistem komunikasi yang dipakai oleh audiens risälah. Sistem komunikasi di sini adalah bahasa Arab dan konteks sosial kebudayaan audiens pertama Alquran. Dalam hal ini, nubuwwah sebagai fenomena sosial keagamaan yang hidup di dalam masyarakat Arab berfungsi menanamkan pemahaman bahwa risälah Nabi Muhammad bukan datang dari sembarang sumber, sehingga audiens pertama memperhatikan serius wahyu yang disampaikan.

Konsep wahyu dalam Islam yang mengaitkan konsep nubuwwah dan risälah mempunyai implikasi hermeneutis terkait bagaimana teks Alquran harus dipahami. Perlu digarisbawahi bahwa wahyu Alquran termanifestasikan dalam sistem bahasa manusia dan berkembang dalam konteks kesejarahan manusia. Wahyu sebenarnya lebih banyak berbicara untuk manusia daripada berbicara untuk Tuhan. Oleh karena itu, prinsip utama dalam memahami wahyu sebenarnya adalah dengan memahami sejarah dan dinamika kehidupan manusia daripada 'kehidupan Tuhan' yang berada di luar nalar manusia. Dalam hal ini, Abū Zayd memandang bahwa usaha-usaha dalam memahami Alquran yang hanya fokus pada "sumber wahyu" saja sama halnya dengan pengabaian terhadap karakter teks dan fungsinya dalam realitas kehidupan dan kesejarahan manusia. Abū Zayd ingin menegaskan bahwa memahami Alquran perlu lebih memperhatikan aspek antroposentris dan humanis daripada teosentris, yang telah lama menjadi tren dominan dan tradisi hegemonik dalam tradisi tafsir Muslim, ${ }^{33}$ karena wahyu Alquran terbentuk dalam kesejarahan manusia, dan risalah Alquran juga ditujukan tidak lain hanya untuk manusia.

Pembacaan humanis wahyu Alquran menemukan urgensinya dalam upaya menanamkan risälah dalam konteks masyarakat yang jauh berbeda dengan konteks wahyu. Di masa modern, kelompok Muslim reformis utilitarianis menekankan maslahah sebagai prinsip payung dalam memahami syariah. Prinsip maslahah dipandang menawarkan

32 Abū Zayd, Mafhūm al-Nass, 63.

33 Ibid., 65. 
prospek manifestasi risälah yang humanis, yang peka terhadap dinamika masyarakat Muslim di setiap zaman. ${ }^{34}$ Dengan maslahah, risalah mampu hadir memberikan petunjuk etis bagi permasalahan umat Islam di setiap zaman.

\section{Wahyu Sebagai Legitimasi Spiritual Keagamaan}

Ketika Nabi Muhammad menyampaikan wahyu Alquran, salah satu pertanyaan utama yang muncul adalah pertanyaan legitimasi. Pertanyaan ini menyangkut otorisasi bahwa apa yang disampaikan Nabi bukan bersumber dari jin atau setan sebagaimana interpretasi kultural audiens pertama Alquran yang familiar dengan fenomena syair dan ramalan. Respons Alquran dalam ayat-ayat Makkiyah awal adalah bahwa apa yang disampaikan Nabi bersumber dari "utusan yang mulia" (rasūl karim; QS. 81:19) atau utusan "yang sangat kuat" (shadìd al-quwā; QS. 53:5) yang bersemayam di ufuk yang tinggi dan terang.

Ketika resistensi dan tekanan terhadap misi Nabi makin kencang, terutama ketika Alquran mulai mengkritik keras pola hidup orang kaya Makkah (QS. 90:4-16; 107:1-6) yang mengabaikan kelompok sosial marginal: yatim, miskin dan budak, dengan demikian mereka telah menyalahi nilai solidaritas kesukuan lama, ${ }^{35}$ Alquran mulai menyebut kisah-kisah para nabi terdahulu sebagai penguat legitimasi Nabi Muhammad. Wahyu mulai memperluas horizon dari hanya sekedar horizon kesukuan Makkah; wahyu mulai mengafiliasi risalah Nabi dengan oikumene agama Abrahamik yang telah menjadi tradisi populer di Jazirah Arab dan wilayah sekitar. Alquran memuat cerita nabi-nabi terdahulu yang menerima wahyu dan diperintahkan menyampaikan wahyu tersebut kepada umatnya dengan segala rintangan yang dihadapi. Alquran kemudian menegaskan bahwa misi Nabi Muhammad tidak lain adalah untuk membenarkan dan melanjutkan misi monotesime para nabi terdahulu (QS. 6:92; 10:37; 12:111; 35:31; 46:12, 30; 61:6). Pertanyaan seputar legitimasi ini tidak hanya muncul di periode Makkah saja. Di Madinah yang menjadi basis komunitas Yahudi kala itu, pertanyaan legitimasi ini juga muncul. Pertanyaan ini dilatari oleh stigma sosial tentang wahyu sebagai

\footnotetext{
34 Wael B. Hallaq, A History of Islamic Legal Theories (Cambridge dll.: Cambridge University Press, 1997), 207-31.

${ }^{35}$ Lihat William Montgomery Watt, Muhammad at Mecca (Oxford: Oxford University Press, 1953).
} 
fenomena eksklusif keagamaan dalam tradisi ahli kitab. Alquran memberikan respons yang sama, menegaskan misi Nabi sebagai kelanjutan misi nabi-nabi terdahulu (QS. 2:89, 97, 101; 3:3; 4:47, 163; 5:48).

Respons wahyu di atas menunjukkan bahwa cerita tentang nabinabi terdahulu sudah cukup dikenal dalam kultur Arab pra-Islam. Jika audiens Alquran tidak familiar dengan cerita-cerita tersebut, mereka tentu saja akan sulit memahami Alquran, atau setidaknya sulit merespons isu-isu yang dimuat di dalam Alquran. Di sini, Nabi menegaskan legitimasinya bahwa pesan yang diterimanya tidak lain adalah pesan yang sama yang diterima oleh nabi-nabi yang telah dikenal dalam kultur Arab pra-Islam. Legitimasi Nabi yang disandarkan pada legitimasi kenabian nabi-nabi terdahulu membantu visualisasi gagasan yang lebih abstrak bahwa risalah monoteisme yang dibawa Nabi berasal dari sumber yang sama, Tuhan Yang Maha Esa.

Memang benar bahwa tradisi kenabian relatif absen dalam kultur Arab pra-Islam. Namun, ini tidak berarti bahwa wacana dan ajaran kenabian juga absen dalam kehidupan mereka. Interaksi dengan ahli kitab menjelaskan bahwa konsep kenabian telah dikenal dalam kultur Arab pra-Islam. Literatur tafsir dan sirah menyebutkan bagaimana orang Arab pra-Islam menjadikan ahli kitab sebagai otoritas dan referensi bagi topik-topik kenabian. Merespons misi Nabi Muhammad, Quraish mengutus 'Utbah b. Abī Mu'ith (m. 2/624) dan al-Naḍr b. al-Ḥārith (m. 2/624) ke Madinah untuk bertemu para tokoh Yahudi di sana dan menanyakan perihal Nabi Muhammad yang mengklaim nubuwwah dan mengemban risälah. Tokoh Yahudi menjawab agar Quraish menanyakan tiga hal kepada Nabi: tentang Aṣhāb al-Kahf, Dhū al-Qarnayn, dan ruh. Jika Nabi Muhammad bisa menjawabnya, maka ia adalah nabi; namun, jika tidak mampu menjawabnya, maka ia adalah pendusta. Sesampainya di Makkah, tiga hal tersebut ditanyakan kepada Nabi. Setelah beberapa hari, wahyu turun menjawab pertanyaan tersebut. ${ }^{36}$ Terlepas benar atau tidak riwayat di atas, kita dapat melihat bahwa narasi Islam tentang kenabian menunjukkan absennya tradisi tersebut di kultur Arab praIslam sehingga mereka harus merujuk kepada otoritas di luar kultur mereka. Dalam konteks Makkah, pertanyaan ini membuat audiens pertama Alquran kesulitan mengidentifikasi klaim kenabian Nabi

${ }^{36}$ Fakhr al-Dīn al-Rāzì, Mafätīh al-Ghayb, ed. Hānī al-Hāijj dan 'Imād Zakī al-Bārūdī, vol. 21 (Kairo: Al-Maktabah al-Tawfīiīyah, t.t.), 53, 75, 148. 
Muhammad dalam kaca mata tradisi mereka. Ketika klaim kenabian itu menjadi isu publik, mereka tahu ke mana mereka harus bertanya, yaitu kepada ahli kitab yang dianggap hidup dalam tradisi tersebut.

\section{Wahyu, Mukjizat, dan Revolusi Hirarki Teks}

Wahyu Alquran membawa efek paradigmatik bagi kehidupan sosial keagamaan audiens pertamanya. Al-Qur'an diyakini sebagai ipsissima verba dei (Firman Tuhan yang murni) melalui agensi kenabian Muhammad. Sumber wahyu yang ilahi ini memunculkan persepsi kekudusan yang membuat umat Islam memperlakukan Alquran dengan sangat hati-hati. Setiap kata dipilih secara ilahi, dan oleh karenanya, ia mengandung pesan yang tidak sembarangan. Dari status suci ini, Alquran muncul sebagai teks Islam yang paling istimewa dan paling superior di atas teks-teks sejenisnya. Doktrin teologis ini dikenal dengan ijär. (melemahkan), doktrin tentang kemampuan Alquran dalam menundukkan teks dan wacana lawan bicaranya. ${ }^{37}$ Karena status inilah, setiap kata dan struktur dari Alquran diyakini mengandung makna tertentu, karena secara sosiologis, semakin istimewa dan bergengsi sebuah teks, semakin penting makna dari setiap kata yang dimuatnya. ${ }^{38}$

Sebenarnya pesan yang disampaikan Alquran tidak seutuhnya merupakan hal yang baru. Cerita-cerita Alquran tentang nabi-nabi terdahulu dengan mudah didapat dalam tradisi keagamaan Abarahamik sebelumnya. Ritual keagamaan seperti haji dan arah kiblat juga sudah dikenal oleh masyarakat Arab pra-Islam. Artinya, Alquran dalam level tertentu berbagi kemiripan dengan teks dan tradisi lain. Namun, mengapa Alquran memiliki signifikansi keagamaan yang berbeda bagi penganutnya dari teks dan tradisi yang dikenal pada masa itu? Munculnya al-Qur'an memicu perubahan radikal dalam hierarki teks pada abad ke-7 di Jazirah Arab. Bagi Muslim generasi pertama, al-Qur'an telah menurunkan derajat teks-teks Arab pagan, jika memang ada, dan telah menggeser otoritas teks-teks keagamaan yang dikenal pada saat itu, seperti Taurat dan Injil, ke posisi marjinal. ${ }^{39}$

Keberhasilan Alquran merebut puncak hirarki teks di mata audiens pertamanya dapat dijelaskan melalui dua konsep yang inheren

\footnotetext{
37 Abū Zayd, Mafhüm al-Nașs, 155.

38 Peter Heath, "Creative Hermeneutics: A Comparative Analysis of Three Islamic Approaches," dalam Arabica, vol. 36, no. 2 (1989): 182.

39 Ibid., 177.
} 
di dalam Alquran, yaitu al-qur'än dan al-kitäb yang bekerja secara dinamis merespons otoritas pada zamannya. Al-qur'ān memainkan peran sebagai teks paradigmatik dalam tradisi oral masyarakat Arab, sementara al-kitäb memainkan peran dalam mentrasnformasi tradisi masyarakat dari budaya oral ke budaya baca-tulis.

Al-qur'ān adalah nama paling awal yang dipakai untuk menunjuk wahyu yang turun kepada Nabi. Penggunaan istilah al-qur'ān di dalam Alquran mengindikasikan makna membaca dalam arti "melafalkan" atau "melantunkan" (tardid $)$. Makna ini didukung oleh fakta bahwa "membaca" sebagai aktivitas memahami material tertulis tidak mungkin diimaginasikan di dalam masyarakat dengan budaya oral yang dominan, sementara budaya baca-tulis tidak memainkan peran yang penting. ${ }^{40}$ Narasi tentang proses pewahyuan sendiri mengindikasikan proses pelantunan oleh Nabi Muhammad dari Jibril. Alquran sendiri menegaskan aspek pelantunan ini dengan kata tartil (QS. 73:4). Alquran dalam makna ini lebih banyak merespons tradisi pelantunan syair dalam kultur Arab pra-Islam. Abū 'Uthmān 'Amr alJāhiz (m. 255/869) mengatakan bahwa nama Alquran secara umum merespons kumpulan syair Arab yang disebut sebagai dìnān; surahnya merespons bagian diwwān, yaitu qasidah; ayatnya merespons bait; dan fäsilah Alquran merespons qäfiyah. ${ }^{41}$

Absennya kata Alquran dari teks-teks Arab pra-Islam mendorong sarjana Barat untuk melacak asal-usul kata ini dengan melihat padanan kata ini di dalam bahasa yang masih serumpun dengan bahasa Arab. Al-qur'àn tampak memiliki paralel di dalam bahasa Suryani, yaitu qeryāna yang juga berarti "membaca". Namun, membaca di sini menekankan pada aspek pelantunan ayat dari kitab suci untuk tujuan ibadah. ${ }^{42}$ Penekanan pada fungsi ritual pembacaan Alquran tampak dalam ayat seperti QS. 17:78 yang menunjukkan bagaimana Alquran menjadi bacaan dalam salat sejak tergelincirnya matahari di siang hari hingga gelapnya malam dan waktu fajar, dan QS. 7:204 yang berisi perintah untuk mendengarkan Alquran ketika sedang dilantunkan. ${ }^{43}$

\footnotetext{
40 Abū Zayd, Mafbüm al-Nașs, 59.

41 Al-Suyūtūi, Al-Itqān, vol. 1, 143.

42 Arthur Jeffery, The Foreign Vocabulary of the Qur'an (Leiden \& Boston: Brill, 2007), 234; Christoph Luxenberg, The Syro-Aramaic Reading of the Koran: A Contribution to the Decoding of the Language of the Koran (Berlin: Hans Schiller, 2007), 120.

${ }^{43}$ QS. 17:78, "Dirikanlah shalat pada saat tergelincirnya matahari hingga gelapnya malam dan bacaan pada saat fajar. Sesungguhnya bacaan fajar itu disaksikan."
} 
Sementara itu, penyebutan Alquran sebagai al-kitāb mengindikasikan pergerakan dinamis dalam kultur Arab pra-Islam. Penyebutan al-kitäb mengindikasikan pesan migrasi dari tradisi oral ke tradisi baca-tulis. Alquran sendiri menyebut beberapa media tulis seperti buku (kitāb; QS. 2:2; 38:29), papirus (qirtās; QS. 6:7, 91), tablet (law); QS. 7:145, 150, 154; 54:13; 85:22), dan kumpulan halaman (subuf; QS. 53:36; 87:19) yang dapat diakses hanya jika seseorang mempunyai kompetensi baca-tulis. Kebijakan Nabi di Madina, di mana gagasan al-kitäb mulai menguat, yang mendorong pengikutnya untuk belajar membaca dan menulis menunjukkan pergerakan dinamis ke arah kultur baru. Dalam riwayat peperangan Nabi, mengajar baca-tulis menjadi salah satu opsi bagi tawanan perang untuk menebus kebebasannya. ${ }^{44}$ Kebijakan Nabi tentang baca-tulis ini tampaknya terkait erat dengan visi Nabi tentang penulisan Alquran. ${ }^{45}$ Dengan kata lain, al-kitäb seakan menghembuskan kesadaran menulis yang mengubah worldview audiens pertama dari budaya dominan Arab yang bersandar pada tradisi lisan menuju budaya baru, budaya tulis yang diskursif. ${ }^{46}$

Di samping itu, penyebutan al-kitāb juga terkait dengan isu sosiologis di Jazirah Arab. Pada masa pra-Islam, al-kitāb menjadi simbol kelompok sosial keagamaan tertentu, yaitu ahli kitab. Karena masyarakat Arab tidak mempunyai tradisi baca kitab suci, maka mereka sering disebut sebagai ummìyun (lit. buta huruf). Sejak di Madinah Nabi Muhammad mulai intensif terlibat perdebatan dengan ahli kitab yang menanyakan legitimasi kenabiannya. Penyebutan Alquran dengan al-kitäb adalah salah satu respons terhadap pertanyaan legitimasi tersebut. Muhammad adalah nabi yang membawa risalah dengan kitab suci, yaitu Alquran, sebagaimana nabi-nabi terdahulu dalam tradisi mereka. Dengan demikian, wahyu turut mengangkat posisi sosial Arab, sejajar dengan ahli kitab, atau bahkan lebih dari itu,

QS. 7:204, “Dan ketika al-Qur'an dibaca, maka dengarkanlah dan diamlah agar kalian mendapat rahmat."

${ }^{44}$ Aḥmad b. Hanbal, Musnad al-Imām Aḥmad b. Hanbal, ed. Shu'ayb al-Arna'ūt, vol. 4 (Beirut: Mu'assasat al-Risālah, t.t.), 92; hadis no. 2216.

45 "Lā taktubù 'annī, wa man kataba 'annì ghayr al-qur'ān fa li yambuh," hadis no. 3004/5326. Abū al-Husayn Muslim b. al-Hajjāj, Sahīḥ Muslim, ed. Muhammad Fu’ād 'Abd al-Bāqī (Kairo: Dār al-Ḥadīth, 1991).

46 Angelika Neuwirth, “The 'Discovery of Writing' in the Qur'an: Tracing an Epistemic Revolution in Late Antiquity," dalam NUN Jurnal Studi Alquran dan Tafsir di Nusantara, vol. 2, no. 1 (2016): 25-56. 
mengingat Alquran muncul sebagai teks paling utama dalam proses sosial dan sejarah umat Islam. Dengan kata lain, wahyu yang juga disebut al-kitāb ini tidak hanya bekerja sebagai pembeda dari kultur masyarakat $u m m i$, namun di saat yang sama juga menjadi pembeda dari tradisi ahli kitab karena kitab yang diterima Nabi Muhammad "berbahasa Arab", ${ }^{47}$ sementara kitab-kitab yang dibaca ahli kitab ditulis dalam bahasa selain Arab (QS. 41:44).

\section{Kesimpulan}

Jika sepanjang sejarah Islam Alquran dipandang sebagai teks paradigmatik yang menjadi payung bagi produksi teks-teks keagamaan Islam oleh para sarjana Muslim, maka pada awal kemunculannya wahyu Alquran merupakan kejadian sosial keagamaan paling fenomenal. Dalam perspektif fenomenologis, wahyu Alquran merupakan tindakan Tuhan yang masuk dalam sejarah manusia, dan oleh karenanya bekerja menyesuaikan hukum-hukum kesejarahan dan kebudayaan manusia. Wahyu tersebut mengadopsi bahasa manusia, berdialektika dengan masalah-masalah yang dihadapi manusia, dan mengekspresikan pesan ketuhanan melalui horizon manusia. Karena Tuhan tidak menyampaikan 'pesan-Nya' kepada setiap individu, maka wahyu Tuhan tersebut disampaikan melalui agensi seorang Nabi (Muhammad) yang berperan dalam menghubungkan horizon ketuhanan dengan horizon kemanusiaan.

Keberhasilan wahyu Alquran dalam perpektif audiensnya terletak pada kekuatan legitimasinya. Dalam kultur Arab pra-Islam, komunikasi antara manusia dan entitas metafisik bukanlah sesuatu yang asing, dan oleh karenanya tertolak secara kultural. Wahyu Alquran juga bekerja dalam langue audiens pertamanya, namun dengan memperkenalkan parole unik yang siap berkompetisi dengan paroleparole yang telah ada dengan tujuan untuk menunjukkan superioritasnya. Dengan demikian, proses pewahyuan Alquran tidaklah terpisah dari nalar audiens pertamanya. Wahyu tersebut membuat distingsi dengan memperkenalkan nama dan konsep baru yang mengisi peran sumber, agensi, dan media wahyu. Alquran menegaskan wahyu yang bersumber dari Allah (bukan jin), muncul melalui agensi Nabi Muhammad (bukan seorang penyair maupun peramal), dan dalam media kitab suci (bukan syair atau ramalan bersajak). Pada masa kemunculannya, wahyu Alquran menjadi

${ }^{47}$ Abū Zayd, Mafbüm al-Nasss, 61. 
fenomena sosial keagamaan yang paradigmatik karena kiprahnya dalam merevolusi mindset audiens pertamanya menuju masyarakat baca-tulis, dan menghembuskan kepercayaan diri mereka untuk berkompetisi dalam wacana keagamaan dengan komunitas keagamaan yang lebih tua.

\section{Daftar Pustaka}

'Itr, Nūr al-Dīn. 'Ulūm al-Qur'ān al-Karim. Damaskus: Maṭba'at alȘabāh, 1993.

Abū Zayd, Nașr Ḥāmid. Al-Tafkèr fì Zaman al-Takfiri. Kairo: Sīnā‘ li alNashr, 1995. Mafbüm al-Nașs: Dirāsat fì 'Ulüm al-Qur'ān. Kairo: Al-Hai'ah al-Mișrīyah al-'Āmmah li al-Kitāb, 1990. "The Dilemma of the Literary Approach to the Qur'an." Alif: Journal of Comparative Poetics 23 (2003).

Bāqillānī (al), Abū Bakr Muḥammad b. al-Ṭayb. I'jāra al-Qur'ān, ed. Aḥmad Șaqar, t.tp: tp, t.t.

Bukhārī (al), Abū 'Abd Allāh Muḥammad b. Ismāî̀l. Șahīḥ al-Bukhārī. Damaskus \& Beirut: Dār Ibn Kathīr, 2002.

Ḥajjāj (al), Abū al-Ḥusayn Muslim. Saḩ̄ḥ Muslim, ed. Muḥammad Fu'ād 'Abd al-Bāqī. Kairo: Dār al-Hadìth, 1991.

Hallaq, Wael B. A History of Islamic Legal Theories. Cambridge: Cambridge University Press, 1997.

Hanafĩ (al), Șa'd al-Dīn 'Alī b. Abī al-'Izz. Sharḥ al-Ṭạ̣āwìyah. Riyad: Wizārat al-Shu'ūn al-Islāmīyah wa al-Awqāf wa al-Da'wah wa al-Irshād, 1997.

Hanbal (ibn), Aḥmad. Musnad al-Imām Aḥmad b. Hanbal, ed. Shu'ayb al-Arna'ūt. Beirut: Mu'assasat al-Risālah, t.t.

Heath, Peter. "Creative Hermeneutics: A Comparative Analysis of Three Islamic Approaches." Arabica, vol. 36, no. 2 (1989).

Ḥusayn, Ṭāhā. Fì al-Shír al-Jāhilì. Kairo: Dār al-Kutub al-Mișrìyah, 1926.

Isḥāq (ibn), Muḥammad. Al-Sìrah al-Nabawìyah, ed. Aḥmad Farīd alMazīīi. Beirut: Dār al-Kutub al-'Ilmīyah, 2004.

Izutsu, Toshihiko. God and Man in the Qur'an: Semantics of the Qur'anic Weltanschaunng, ed. ke-2. Petaling Jaya: Islamic Book Trust, 2008. 
. "Revelation as a Linguistic Concept in Islam." dalam Studies in Medieval Thought 5 (1962).

Jeffery, Arthur. The Foreign Vocabulary of the Qur'an. Leiden \& Boston: Brill, 2007.

Khaldūn (ibn), 'Abd al-Raḥmān. Al-Muqaddimah, ed. 'Abd al-Salām alShadādī. Casablanca: Bayt al-Funūn wa al- Ulūm wa al-Ādāb, 2005.

Khūīi (al), Amīn. Manähij al-Tajdìd fì al-Naḥw wa al-Baläghah wa al-Tafsìr wa al-Ādäb. Kairo: Maktabat al-Usrah, 2003.

Luxenberg, Christoph. The Syro-Aramaic Reading of the Koran: A Contribution to the Decoding of the Language of the Koran. Berlin: Hans Schiller, 2007.

Messick, Brinkley Morris. The Calligraphic State: Textual Domination and History in a Muslim Society. Berkeley, LA \& London: University of California Press, 1996.

Neuwirth, Angelika. Scripture, Poetry and the Making of a Community: Reading the Qur'an as a Literary Text. Oxford: Oxford University Press, 2014.

"The 'Discovery of Writing' in the Qur'an: Tracing an Epistemic Revolution in Late Antiquity." NUN, vol. 2, no. 1 (2016).

Nöldeke, Theodor. Neue Beiträge Zur Semitischen Sprachwissenschaft. Straßburg: Verlag von Karl J. Trübner, 1910.

Qālī (al), Abū 'Alī Ismā'īl b. al-Qāsim. Kitāb al-Amālì wa al-Zayl wa alTanbị̄. Kairo: Al-Hai’ah al-Mișrīyah al-'Āmmah li al-Kutub, 1975.

Qattān (al), Mannā‘. Mabāhith fì 'Ulüm al-Qur'ān. Kairo: Maktabat Wahbah, 2000.

Qurțubī (al), Abū 'Abd Allāh. Al-Jāmi' li Aḥkām al-Qur'ān, ed. 'Abd Allāh b. 'Abd al-Muhsin al-Turkī. Beirut: Mu'assasat al-Risālah, 2006.

Rāzī (al), Fakhr al-Dīn. Mafâtīh al-Ghayb, ed. Hānī al-Hāàj dan 'Imād Zakī al-Bārūdī. Cairo: Al-Maktabah al-Tawfíqiyyah, t.th.

Saussure, Ferdinand de. Course in General Linguistics, terj. Wade Baskin. New York: The Philosophical Library, 1959.

Shākir, Aḥmad Muḥammad dan 'Abd al-Salām Muhammad Hārūn (eds.). Al-Mufaddalīyāt. Kairo: Dār al-Ma'ārif, 1942.

Suyūṭī (al), Jalāl al-Dīn. Al-Itqān fì Ulùm al-Qửàn. Kairo: Dār alTurāth, 1985. 
Syamsuddin, Sahiron. Hermeneutika dan Pengembangan Ulumul Qur'an, Edisi Revisi dan Perluasan. Yogyakarta: Nawesea Press, 2017.

Tymieniecka, Anna-Teresa. "Introduction: Phenomenology as the Inspirational Force of Our Times." Anna-Teresa Tymieniecka (ed.). Phenomenology World-Wide. Dordrecht: Springer Science+Business Media, 2002.

Watt, William Montgomery, Mubammad at Mecca. Oxford: Oxford University Press, 1953.

Zarkashī (al), Badr al-Dīn. Al-Burbān fì Ulüm al-Qư'ān, ed. Muhammad Abū al-Faḍl Ibrāhīm. Kairo: Dār al-Turāth, 2000.

Zawzan̄i (al), Abū 'Abd Allāh al-Ḥusayn b. Aḥmad. Sharḥ al-Mu'allaqāt al-Sab؛ Beirut: Lajnat al-Taḥī̄ fī al-Dār al-`Ālamīyah, 1992. 